\title{
Analysis of physicochemical water quality parameters for streams under agricultural, urban and forest land-use types: in the case of gilgel Gibe catchment, Southwest Ethiopia
}

\author{
Berhanu Zawude Bakure ${ }^{1}$ D $\cdot$ Samuel Fikadu² $\cdot$ Asgdom Malu $^{2}$
}

Received: 30 October 2018 / Accepted: 16 October 2020 / Published online: 3 November 2020

(c) The Author(s) 2020

\begin{abstract}
Streams draining to Gilgel Gibe catchment cross agricultural and urban land uses receiving a different pollutant that challenges water quality. A total of 21 sampling sites were selected from seven streams of agricultural $(n=3)$, urban $(n=3)$ and forest $(n=1)$ land-use types. Composite samples were collected from upstream, middle and downstream of all land-use types. Twenty-three physicochemical parameters were measured from each sampling site. Temperature, DO, pH, EC, turbidity, width, depth, current velocity and discharge were measured onsite. Two milliliters of unfiltered water samples was collected from every site for laboratory analysis. Mean of $\mathrm{NO}_{3}-\mathrm{N}$ was highest in agricultural streams than forested and urban streams. In contrast, mean of SRP, $\mathrm{NH}_{4}-\mathrm{N}$ and $\mathrm{COD}$ and $\mathrm{BOD}_{5}$ concentration was greater in urban streams followed by agricultural streams, whereas forest streams are lowest. Concentrations of nutrients, EC and turbidity were recorded in increasing manner across land-use gradient from forested to agricultural and urban streams. The analysis of one-way ANOVA showed that all physicochemical parameters were significantly different among all sites with different land-use types $(P<0.05)$, except for water temperature (one-way ANOVA: $F=0.987, \mathrm{P}=0.494$ ). NMDS and cluster analyses have discriminated the sites into three groups of land-use types. Then, we conclude that water quality of urban stream is highly impaired than agricultural streams, whereas forested streams have better water quality. Therefore, stream restoration projects, reforestation, conservation of riparian vegetation appropriate waste disposal need to be encouraged in the study area for sustainable management of freshwater resources.
\end{abstract}

Keywords Water quality $\cdot$ Land-use types $\cdot$ Reference stream $\cdot$ Physicochemical parameters

\section{Introduction}

Freshwaters are precious and very scarce resources (Gardner and Engelman 1997; Rock 1998; Ridoutt and Pfister 2010; Arjen and Hoekstra 2010) on which our daily life is based in order to sustain on this planet. Nowadays, the fundamental challenge of freshwater quality is derived from anthropogenic activities such as industrialization (Ebenstein 2012; Teng et al. 2011; Temesgen and Seyoum 2018), urbanization

Berhanu Zawude Bakure

Berzew5@gmail.com

1 Department of Environmental Science, College of Natural and Computational Science, Wollega University, P.O. Box 395, Nekemte, Ethiopia

2 Department of Environmental Health Science and Technology, College of Health Science, Jimma University, P.O. Box: 378, Jimma, Ethiopia
(Luo et al. 2017; Ren et al. 2003; Pires et al. 2015) and intensive agricultural activities (Buda and DeWalle 2009; Hall and Leavit 1999; Lenat 1984; Ren et al. 2003). Conversion of land from one land-use type to other land use can adversely affect the quality of freshwater (Bernot et al. 2010; Yu et al. 2016; Likens and Bormann 1974).

Modification of land surface for human use from forest to agriculture and then from agriculture to urban is common practices in developing countries (Pires et al. 2015; Buda and DeWalle 2009; Yu et al. 2016; Ren et al. 2003; Wallace et al. 1997; Mulholland 1992) like Ethiopia. These have drastically inflicted water quality parameters (Kail et al. 2012; Hall and Leavitt 1999). As streams pass through different land-use types, they receive various chemical contaminants (Ding et al. 2016; Bernot et al. 2010; Likens and Bormann 1974). The pollutant types that worsen water quality may vary for different land-use types (Yu et al. 2016; Zhou et al. 2016; Bu et al. 2014). These depend on the purpose 
for which land is used like crop cultivation, pastoral, healthcare centers, residential places and institutions that discharge wastes without enough treatment (Chang 2008; Waziri and Ogugbuaja 2010; Mereta et al. 2012).

Overgrazing and crop cultivation lead to poor water quality (Yu et al. 2016; Mereta et al. 2012; McGrane 2016; Luo et al. 2017). Chemical residues such as manure, fertilizers and pesticides (De Gerónimo et al. 2014; Mekonen et al. 2016) from intensive cultivation of crops percolate to groundwater and move to streams posing health risk. Fertilizers have adverse impact on water resources as increased nutrient concentration can cause pathogens and vectors to disseminate (Wondim et al. 2016; Buda and DeWalle 2009). In addition, increased concentration of nutrients such as phosphate and nitrate in stream directs to excessive algal growth, which deteriorates water quality, poses health risk, depletes dissolved oxygen and increases water temperature (Lenat 1984; Li et al. 2008).

As urbanization is expanding with population growth, different organic and inorganic chemical compounds are discharged to rivers (Temesgen and Seyoum 2018; Buda and DeWalle 2009; Bernot et al. 2010; Yu et al. 2016; McGrane 2016). Runoff takes oil, grease, household chemicals and domestic wastes to the streams. Due to these streams are threatened by excessive and high loads of organic waste (Wondim et al. 2016; Buda and DeWalle 2009; Zhou et al. 2016). River pollution first influences chemical quality, then followed by disquieting aquatic organisms and delicate food web. Because of these, the physicochemical qualities of streams crossing through different land-use types become major concerning issue for today's authors.

The catchment of Gilgel Gibe River is characterized by fast urban expansion and intensive agricultural activities. Thus, physicochemical qualities of streams crossing these land uses were threatened by human activities at the catchment area (Mereta et al. 2012). In order to assess the extent to which different land-use types affect water quality, we have included samples from urban and agricultural land uses as study site and forest streams as reference sites.

There was no research done on physicochemical water quality of streams draining across agricultural, urban and forest streams. Therefore, the aim of this study was to analyze the physicochemical water quality parameters of streams under agricultural, urban and forest land uses at Gilgel Gibe catchment.

\section{Methods and materials}

\section{Study area}

This study was conducted in Gilgel Gibe catchment streams located in Jimma zone of Southwest Ethiopia (Fig. 1). Data were collected from three agricultural streams (Merewa, Gibe and Gulufa), three urban streams (Kito, Kochi and Awetu) and one forest stream. The study area was characterized by fast-growing urban and intensive agricultural activities. As it was reported by Mereta et al 2012 overgrazing, brick preparation, vegetation removal and land conversion to cropland, drainage, municipal waste discharge and crop cultivation are the major threats of human activities around these study streams. Maize (Zea mays), teff, sorghum, barley and wheat cultivation is commonly practiced at the Gilgel Gibe watershed. Conversely, forest stream was characterized by the absence of human activities. All sites of forest stream have no any proportion of agricultural land use and human disturbance; rather, natural vegetation is restricted to state protection in upper stream. Therefore, overall hills were covered by vegetation and protected by government.

\section{Water sampling sites}

A total of 21 sampling sites were taken from seven streams that drain agricultural $(n=3)$, urban $(n=3)$ and forest $(n=1)$ catchments. All steams are permanent and they flow throughout the year. Samples were taken from upstream, middle stream and downstream of all land-use types. From urban streams, Awetu (A1, A2, and A3 sampling sites), Kochi (KO1, KO2 and KO3 sampling sites) and Kito (K1, $\mathrm{K} 2$, and $\mathrm{K} 3$ sampling sites) were selected. Correspondingly, from agricultural streams, Merewa (M1, M2 and M3 sampling sites), Gibe (G1, G2 and G3 sampling sites) and Gulufa (GU1, GU2 and GU3 sampling sites) were selected. For forest stream, F1, F2 and F3 were chosen. In these symbols, letters refer to the name of streams and numbers 1,2 and 3 illustrate upstream, middle stream and downstream, respectively.

\section{Water sampling and measurements}

Water samples were collected during the wet season of the region from May to June 2017. Onsite measurement was suggested for parameters that will be changed overtime due to chemical reactions or biological changes (APHA 1996). Thus, dissolved oxygen (DO), temperature, $\mathrm{pH}$ and electrical conductivity (EC) were measured with multiparameter probe meter (HATCH hd401). Turbidity was also measured onsite using turbid meter (Wag-WT3020). The physical features measured include stream width, depth and adjacent landuse pattern. Current velocity was measured with Vale port's Flow Meter Model 001, and depth was recorded at three to ten evenly spaced points across the wetted width of each site. Discharge was calculated as the wetted width of each site multiplied by its average depth and velocity. Moreover, for incorporation of GIS (Geographic Information System) 

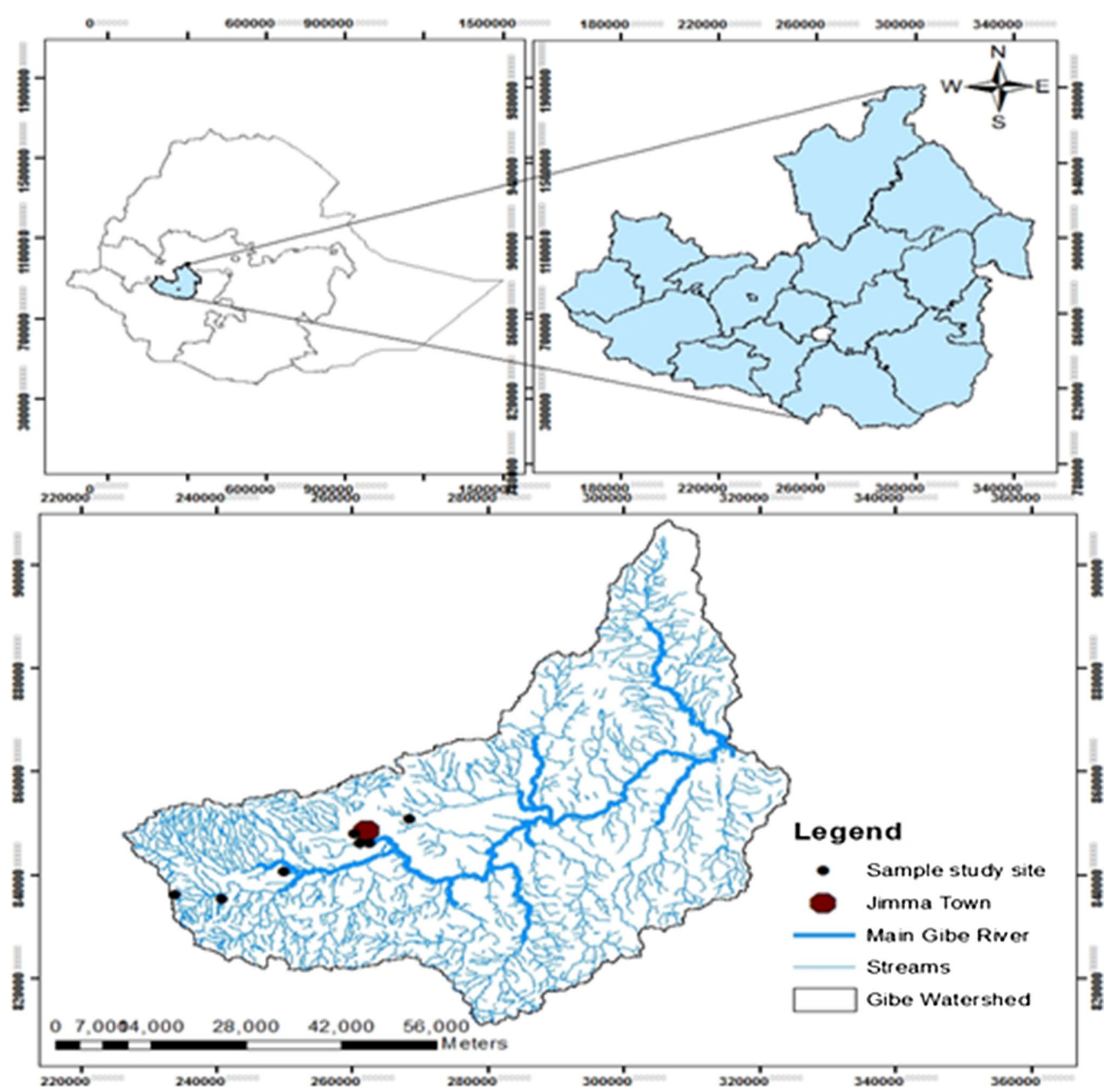

Fig. 1 Map of the study area

database, altitude, longitude and latitude sampling sites were recorded using GPS (global positioning system) reading.

\section{Water sampling and laboratory analysis}

Composite sampling technique was used to take water samples. Two liters of unfiltered water samples was collected using acid-washed polyethylene bottles and transported to Jimma University Environmental Health Laboratory with ice box (below $4{ }^{\circ} \mathrm{C}$ ) for analysis.

\section{Laboratory analysis}

Water samples were analyzed for 5-day biochemical oxygen demand $\left(\mathrm{BOD}_{5}\right)$, chemical oxygen demand (COD), ammonium $\left(\mathrm{NH}_{4}-\mathrm{N}\right)$, soluble reactive phosphorous (SRP) and nitrate nitrogen $\left(\mathrm{NO}_{3}-\mathrm{N}\right)$ according to the standard methods prescribed by APHA (1996). 


\section{Statistical analysis}

Nonmetric multidimensional scaling (NMDS) was used to summarize variation in physicochemical parameters among sampling sites. Dissimilarity matrices based on the Bray-Curtis coefficients (Bray and Curtis 1957) were employed. Goodness of fit of the ordination was assessed by the magnitude of the associated stress value; a value of $<0.2$ corresponds to a good ordination. Differences in water chemistry were compared among sites using one-way analysis of variance (ANOVA) followed by Tukey's post hoc multiple comparison tests. Cluster analysis for all land-use types was made using PAST software. All statistical analyses were performed with Statistica7 (Version7, 2004, Stat Soft, Tulsa, Oklahoma), unless otherwise indicated.

\section{Results and discussion}

The concentrations of stream inorganic nutrients were generally increased across the land-use gradient from forested (Table 3) to agricultural (Table 1) and urban (Table 2) streams. Mean of $\mathrm{NO}_{3}-\mathrm{N}$ was highest in agricultural streams (ranging from $4.8 \mathrm{mg} / \mathrm{l}$ to $7.58 \mathrm{mg} / \mathrm{l}$ ) than forested and urban streams (lowest with range of $0.37 \mathrm{mg} / \mathrm{l}$ to $2.71 \mathrm{mg} / \mathrm{l}$ ). These may be because of landscape change leading to nutrient load in streams sediment (Ding et al. 2016; Bu et al. 2014; Turner and Rabalia 2003; Mouri and Oki 2011).

Among agricultural streams, Gulufa stream sites have the highest $\mathrm{NO}_{3}-\mathrm{N}$ concentration when compared with Merewa and Gibe streams. According to Ding et al. 2016 and Zhou et al. 2016, these reveal that intensive agricultural activities have caused high nutrient measures in the streams. The concentration of nitrate decreased at downstream sites when compared with upstream site for agricultural streams. As it was reported by Zhou et al. 2016, there can be high nutrient concentration at upper stream but the lower concentration recorded in our result at the downstream may be due to denitrification process according to Bohlke and Denver 1995.

From urban streams, the mean of nitrate was highest for Kito followed by Awetu, while the lowest concentration was in Kochi stream. As it was reported by Bu et al. 2014, these have direct relationship with human activities in the city that discharge organic and inorganic waste in Awetu and

Table 1 Mean $( \pm$ SE) values for measured physicochemical characteristics of nine study sites in agriculture catchment

\begin{tabular}{|c|c|c|c|c|c|c|c|c|c|}
\hline & \multicolumn{3}{|c|}{ Merewa stream sites } & \multicolumn{3}{|c|}{ Gibe stream sites } & \multicolumn{3}{|c|}{ Gulufa stream sites } \\
\hline & $M 1$ & $M 2$ & M3 & $G 1$ & $G 2$ & $G 3$ & GU1 & GU2 & GU3 \\
\hline $\begin{array}{l}\text { Ambient } \\
\text { tem- } \\
\text { perature } \\
\left({ }^{\circ} \mathrm{C}\right)\end{array}$ & $24.5 \pm 0.5$ & $23.6 \pm 0.32$ & $19.8 \pm 0.29$ & $23.3 \pm 1.15$ & $22.3 \pm 2.08$ & $22.3 \pm 1.53$ & $24 \pm 1$ & $24.7 \pm 1.15$ & $25.7 \pm 1.53$ \\
\hline Depth (m) & $0.87 \pm 0.01$ & $0.86 \pm 0.01$ & $0.65 \pm 0.01$ & $1.32 \pm 0.1$ & $1.52 \pm 0.08$ & $1.18 \pm 0.06$ & $2.29 \pm 0.04$ & $2.14 \pm 0.1$ & $2.02 \pm 0.03$ \\
\hline $\begin{array}{l}\text { Wet width } \\
\text { (m) }\end{array}$ & $2.27 \pm 0.05$ & $2.24 \pm 0.06$ & $2.31 \pm 0.01$ & $4.43 \pm 0.06$ & $4.15 \pm 0.03$ & $3.66 \pm 0.08$ & $2.88 \pm 0.07$ & $3.16 \pm 0.03$ & $2.84 \pm 0.08$ \\
\hline $\begin{array}{c}\text { Current } \\
(\mathrm{m} / \mathrm{s})\end{array}$ & $0.11 \pm 0.01$ & $0.21 \pm 0.01$ & $0.13 \pm 0.01$ & $0.12 \pm 0.02$ & $0.13 \pm 0.01$ & $0.14 \pm 0.03$ & $0.12 \pm 0.01$ & $0.11 \pm 0.01$ & $0.11 \pm 0.01$ \\
\hline $\begin{array}{c}\text { Discharge } \\
\left(\mathrm{m}^{3} / \mathrm{s}\right)\end{array}$ & $0.21 \pm 0.01$ & $0.32 \pm 0.01$ & $0.174 \pm 0.04$ & $0.6 \pm 0.01$ & $0.74 \pm 0.06$ & $0.63 \pm 0.02$ & $0.96 \pm 0.02$ & $0.67 \pm 0.01$ & $0.58 \pm 0.01$ \\
\hline $\begin{array}{l}\text { Nitrate } \\
\qquad(\mathrm{mg} / \mathrm{l})\end{array}$ & $4.98 \pm 0.06$ & $4.95 \pm 0.08$ & $4.8 \pm 0.031$ & $6.33 \pm 0.06$ & $6.36 \pm 0.07$ & $6.27 \pm 0.03$ & $7.58 \pm 0.12$ & $7.26 \pm 0.12$ & $7.41 \pm 0.18$ \\
\hline $\begin{array}{l}\text { Ammo- } \\
\text { nium } \\
(\mathrm{mg} / \mathrm{l})\end{array}$ & $0.094 \pm 0.0$ & $0.092 \pm 0.0$ & $0.083 \pm 0.0$ & $0.327 \pm 0.01$ & $0.38 \pm 0.01$ & $0.085 \pm 0.01$ & $0.084 \pm 0.0$ & $0.086 \pm 0.0$ & $0.094 \pm 0.0$ \\
\hline $\mathrm{SRP}(\mathrm{mg} / \mathrm{l})$ & $0.071 \pm 0.0$ & $0.074 \pm 0.0$ & $0.075 \pm 0.0$ & $0.053 \pm 0.0$ & $0.052 \pm 0.0$ & $0.05 \pm 0.0$ & $0.125 \pm 0.0$ & $0.13 \pm 0.01$ & $0.125 \pm 0.01$ \\
\hline $\mathrm{pH}$ & $7.87 \pm 0.12$ & $7.230 \pm 0.15$ & $7.56 \pm 0.02$ & $8.15 \pm 0.04$ & $8.06 \pm 0.05$ & $8.16 \pm 0.05$ & $8.53 \pm 0.02$ & $8.17 \pm 0.05$ & $8.32 \pm 0.0$ \\
\hline $\begin{array}{l}\text { Water tem- } \\
\text { perature } \\
\left({ }^{\circ} \mathrm{C}\right)\end{array}$ & $21 \pm 0.5$ & $20.37 \pm 1.0$ & $20.89 \pm 0.84$ & $20.83 \pm 0.29$ & $21.58 \pm 0.09$ & $22.7 \pm 0.25$ & $23.25 \pm 0.67$ & $24.41 \pm 0.25$ & $24.24 \pm 0.05$ \\
\hline $\begin{array}{l}\text { COD } \\
\quad(\mathrm{mg} / \mathrm{l})\end{array}$ & $36.781 \pm 0.02$ & $36.57 \pm 0.11$ & $36.73 \pm 0.48$ & $42.81 \pm 0.2$ & $42.51 \pm 0.04$ & $42.6 \pm 0.33$ & $58.71 \pm 0.08$ & $58.01 \pm 0.03$ & $57.6 \pm 0.1$ \\
\hline $\mathrm{DO}(\mathrm{mg} / \mathrm{l})$ & $6.57 \pm 0.05$ & $6.4 \pm 0.01$ & $6.33 \pm 0.06$ & $6.21 \pm 0.0$ & $6.09 \pm 0.03$ & $6.1 \pm 0.01$ & $5.79 \pm 0.06$ & $5.6 \pm 0.02$ & $5.53 \pm 0.01$ \\
\hline DO $\%$ & $93.42 \pm 0.37$ & $91.7 \pm 0.1$ & $91.51 \pm 0.1$ & $90.69 \pm 0.18$ & $90.6 \pm 0.1$ & $90.6 \pm 0.09$ & $86.86 \pm 0.14$ & $85.81 \pm 0.18$ & $85.8 \pm 0.13$ \\
\hline $\begin{array}{c}\mathrm{EC}(\mu \mathrm{s} / \\
\mathrm{cm})\end{array}$ & $136.1 \pm 0.17$ & $135.78 \pm 0.21$ & $133.77 \pm 0.21$ & $96.3 \pm 0.1$ & $95.28 \pm 0.24$ & $94.77 \pm 0.21$ & $130.7 \pm 0.17$ & $122.8 \pm 0.03$ & $123.1 \pm 0.16$ \\
\hline $\begin{array}{r}\text { Turbidity } \\
\text { (NTU) }\end{array}$ & $33.59 \pm 0.08$ & $32.68 \pm 0.28$ & $31.89 \pm 0.17$ & $37.82 \pm 0.16$ & $36.7 \pm 0.71$ & $36.37 \pm 0.55$ & $45.89 \pm 0.17$ & $45.2 \pm 0.1$ & $42 \pm 0.25$ \\
\hline $\begin{array}{l}\mathrm{BOD}_{5} \\
(\mathrm{mg} / \mathrm{l})\end{array}$ & $0.64 \pm 0.07$ & $0.65 \pm 0.02$ & $0.637 \pm 0.01$ & $0.87 \pm 0.02$ & $0.83 \pm 0.02$ & $0.77 \pm 0.06$ & $1.19 \pm 0.04$ & $1.14 \pm 0.01$ & $1.14 \pm 0.02$ \\
\hline
\end{tabular}


Table 2 Mean $( \pm$ SE) values for measured physicochemical characteristics of nine study sites in urban catchment

\begin{tabular}{|c|c|c|c|c|c|c|c|c|c|}
\hline & \multicolumn{3}{|c|}{ Awetu stream sites } & \multicolumn{3}{|l|}{ Kito stream sites } & \multicolumn{3}{|c|}{ Kochi stream sites } \\
\hline & $A 1$ & $A 2$ & $A 3$ & $K 1$ & $K 2$ & $K 3$ & KO1 & KO2 & KO3 \\
\hline $\begin{array}{l}\text { Ambient } \\
\text { tempera- } \\
\text { ture }\left({ }^{\circ} \mathrm{C}\right)\end{array}$ & $20.37 \pm 0.32$ & $19.9 \pm 0.21$ & $20.2 \pm 0.61$ & $20.67 \pm 0.29$ & $20 \pm 0.06$ & $20 \pm 0.01$ & $20 \pm 0$ & $20.6 \pm 0.35$ & $20.3 \pm 0.58$ \\
\hline Depth (m) & $0.45 \pm 0.17$ & $0.48 \pm 0.0$ & $0.6 \pm 0.2$ & $0.57 \pm 0.57$ & $0.32 \pm 0.33$ & $1.19 \pm 1$ & $0.20 \pm 0.01$ & $0.08 \pm 0$ & $0.12 \pm 0.01$ \\
\hline $\begin{array}{l}\text { Wet width } \\
(\mathrm{m})\end{array}$ & $2.75 \pm 025$ & $3.75 \pm 0.15$ & $4.04 \pm 0$ & $2.17 \pm 1.53$ & $2.23 \pm 0.68$ & $2.73 \pm 1.25$ & $1 \pm 0.01$ & $1.52 \pm 0.04$ & $1 \pm 0.01$ \\
\hline $\begin{array}{l}\text { Current } \\
(\mathrm{m} / \mathrm{s})\end{array}$ & $0.14 \pm 0.06$ & $0.73 \pm 0.05$ & $0.107 \pm 0.06$ & $0.203 \pm 0.14$ & $0.47 \pm 0.37$ & $0.196 \pm 0.09$ & $0.46 \pm 0.0$ & $0.32 \pm 0.0$ & $0.22 \pm 0.0$ \\
\hline $\begin{array}{c}\text { Discharge } \\
\left(\mathrm{m}^{3} / \mathrm{s}\right)\end{array}$ & $0.67 \pm 0.04$ & $1.17 \pm 0.01$ & $0.65 \pm 0.46$ & $0.25 \pm 0.06$ & $0.17 \pm 0.01$ & $0.56 \pm 0.46$ & $0.9 \pm 0.06$ & $0.36 \pm 0.02$ & $0.41 \pm 0.01$ \\
\hline $\begin{array}{l}\text { Nitrate } \\
\text { (mg/l) }\end{array}$ & $0.55 \pm 0.1$ & $0.79 \pm 0.03$ & $2.39 \pm 0.17$ & $0.65 \pm 0.58$ & $1.15 \pm 0.86$ & $2.38 \pm 1.97$ & $0.37 \pm 0.0$ & $0.403 \pm 0.01$ & $2.71 \pm 0.01$ \\
\hline $\begin{array}{c}\text { Ammo- } \\
\text { nium } \\
(\mathrm{mg} / \mathrm{l})\end{array}$ & $0.48 \pm 0.04$ & $0.58 \pm 0.04$ & $0.55 \pm 0.01$ & 0.39 & $0.074 \pm 0.07$ & $0.77 \pm 0.98$ & $14.09 \pm 0.01$ & $16.47 \pm 0.01$ & $13.8 \pm 0.01$ \\
\hline $\mathrm{SRP}(\mathrm{mg} / \mathrm{l})$ & $0.065 \pm 0.05$ & $0.13 \pm 0.02$ & $1.345 \pm 0.04$ & $0.24 \pm 0.0$ & $0.41 \pm 0.0$ & $0.32 \pm 0.0$ & $1.35 \pm 0.004$ & $0.171 \pm 0.0$ & $0.04 \pm 0.0$ \\
\hline $\mathrm{pH}$ & $7.28 \pm 0.08$ & $7.58 \pm 0.28$ & $7.282 \pm 0.21$ & $7.04 \pm 0.55$ & $7.12 \pm 0.51$ & $7.24 \pm 0.61$ & $7.16 \pm 0.0$ & $7.58 \pm 0.0$ & $7.55 \pm 0.0$ \\
\hline $\begin{array}{l}\text { Water tem- } \\
\text { perature } \\
\left({ }^{\circ} \mathrm{C}\right)\end{array}$ & $19.9 \pm 0.2$ & $20 \pm 0.5$ & $20.55 \pm 0.05$ & $18.83 \pm 1.75$ & $20.87 \pm 3.33$ & $20.42 \pm 4.46$ & 18.920 .03 & $18.57 \pm 0.01$ & $21.72 \pm 0.01$ \\
\hline $\begin{array}{l}\text { COD } \\
\qquad(\mathrm{mg} / \mathrm{l})\end{array}$ & $43.01 \pm 0.01$ & $37.2 \pm 0.01$ & $31.3 \pm 0.0$ & $51.21 \pm 0.01$ & $60.97 \pm 0.06$ & $59.96 \pm 0.08$ & $102.9 \pm 0.06$ & $42.20 \pm 0.01$ & $61.60 \pm 0.01$ \\
\hline DO (mg/l) & $5.62 \pm 0.02$ & $2.05 \pm 0.04$ & $0.725 \pm 0.07$ & $6.42 \pm 0.72$ & $7.11 \pm 0.27$ & $6.55 \pm 0.58$ & $3.31 \pm 0.0$ & $4.31 \pm 0.01$ & $5.11 \pm 0.01$ \\
\hline $\mathrm{DO} \%$ & $81.85 \pm 3.85$ & $27.6 \pm 1.2$ & $9 \pm 1.0$ & $80.7 \pm 15.25$ & $74.32 \pm 29.42$ & $50.58 \pm 39.45$ & $43.44 \pm 0.01$ & $56.18 \pm 0.0$ & $70.73 \pm 0.01$ \\
\hline $\mathrm{EC}(\mu \mathrm{s} / \mathrm{cm})$ & $115.75 \pm 2.55$ & $131 \pm 2.0$ & $185.08 \pm 3.83$ & $148.5 \pm 47.8$ & $128.19 \pm 64.65$ & $162.17 \pm 32.85$ & $250 \pm 0.06$ & $291 \pm 0.03$ & $315 \pm 0.02$ \\
\hline $\begin{array}{r}\text { Turbidity } \\
\text { (NTU) }\end{array}$ & $24.55 \pm 3.45$ & $162.5 \pm 2.5$ & $182.5 \pm 2.5$ & $27.33 \pm 3.5$ & $37.57 \pm 8.16$ & $44.27 \pm 14.2$ & $170.4 \pm 0.01$ & $207.5 \pm 0.01$ & $106.49 \pm 0.01$ \\
\hline $\begin{array}{l}\mathrm{BOD}_{5} \\
\quad(\mathrm{mg} / \mathrm{l})\end{array}$ & $27.67 \pm 10.3$ & $52 \pm 1.0$ & $171 \pm 1.0$ & $2.1 \pm 0.1$ & $2.63 \pm 0.32$ & $22 \pm 1.0$ & $66.93 \pm 0.04$ & $27.43 \pm 0.0$ & $40.04 \pm 0.0$ \\
\hline
\end{tabular}

Table 3 Mean $( \pm \mathrm{SE})$ values for measured physicochemical characteristics of three study sites in forest catchment

\begin{tabular}{lccc}
\hline & \multicolumn{2}{c}{$F 1$} & \multicolumn{2}{c}{$F 3$} \\
\hline $\begin{array}{l}\text { Ambient temperature } \\
\left({ }^{\circ} \mathrm{C}\right)\end{array}$ & $20.3 \pm 0.58$ & $19.83 \pm 1.04$ & $20.3 \pm 0.58$ \\
Depth $(\mathrm{m})$ & & & \\
Wet width $(\mathrm{m})$ & $0.51 \pm 0.07$ & $0.64 \pm 0.07$ & $0.55 \pm 0.1$ \\
Current $(\mathrm{m} / \mathrm{s})$ & $0.51 \pm 0.07$ & $0.64 \pm 0.07$ & $0.55 \pm 0.1$ \\
Discharge $\left(\mathrm{m}^{3} / \mathrm{s}\right)$ & $0.132 \pm 0.01$ & $0.076 \pm 0.02$ & $0.14 \pm 001$ \\
Nitrate $(\mathrm{mg} / \mathrm{l})$ & $0.064 \pm 0.01$ & $0.08 \pm 0.0$ & $0.12 \pm 0.03$ \\
Ammonium $(\mathrm{mg} / \mathrm{l})$ & $3.33 \pm 0.05$ & $3.22 \pm 0.07$ & $3.28 \pm 0.03$ \\
SRP $(\mathrm{mg} / \mathrm{l})$ & $0.029 \pm 0.0$ & $0.0291 \pm 0.0$ & $0.024 \pm 0.0$ \\
pH & $0.057 \pm 0.01$ & $0.051 \pm 0.0$ & $0.051 \pm 0.0$ \\
Water temperature $\left({ }^{\circ} \mathrm{C}\right)$ & $20.47 \pm 0.55$ & $21.52 \pm 1.1$ & $22.5 \pm 1.8$ \\
COD $(\mathrm{mg} / \mathrm{l})$ & $34.83 \pm 0.08$ & $34.68 \pm 0.12$ & $34.04 \pm 0.02$ \\
DO $(\mathrm{mg} / \mathrm{l})$ & $7.66 \pm 0.02$ & $7.57 \pm 0.11$ & $7.28 \pm 0.04$ \\
DO\% & $97.55 \pm 0.51$ & $95.08 \pm 0.75$ & $94.41 \pm 0.1$ \\
EC $(\mu \mathrm{s} / \mathrm{cm})$ & $98.24 \pm 0.25$ & $102.743 \pm 0.65$ & $92.8 \pm 0.46$ \\
Turbidity $(\mathrm{NTU})$ & $26.85 \pm 1.78$ & $27.589 \pm 0.52$ & $26.61 \pm 0.57$ \\
BOD $5(\mathrm{mg} / \mathrm{l})$ & $0.53 \pm 0.01$ & $0.43 \pm 0.01$ & $0.22 \pm 0.01$ \\
\hline
\end{tabular}

Kochi sampling sites. But for Kito, there are mixed activities such as agricultural activities from upstream and inappropriate waste disposal at the side of streams. In opposite to agricultural and forest streams, the concentration of nitrate increased downstream of urban sites. This is because rate of nutrient discharge is greater than rate of denitrification and in the stream and agricultural streams have high rate of denitrification (Yogendra and Puttaia 2008; Chang 2008; Waziri and Ogugbuaja 2010; Bohlke and Denver 1995; Mulholland 1992; Mouri and Oki 2011; Bernot et al. 2010). For forest stream sites, concentration of nitrate falls between both agricultural and urban streams and it shows no significant change downstream. This may be due to uniform nutrient input and constant rate of denitrification as reported by Jones et al. 2001; Mullholland 1992; Bernot et al. 2010.

Mean of $\mathrm{NH}_{4}-\mathrm{N}$ is greater in agricultural and urban streams than forest stream. From urban stream site (Table 2), Kochi was the highest and Kito was the lowest in $\mathrm{NH}_{4}-\mathrm{N}$ concentration. Agricultural streams were greater than forest stream sites and lower than urban streams sites in terms of $\mathrm{NH}_{4}-\mathrm{N}$ concentration. As reported by other authors such as Ding et al. 2016, Bu et al. 2014, Bohlke and Denver 1995 and Mulholland 1992, increased human activities lead to 
increase in the concentration of ammonium nitrogen in the freshwater, indicating that quality of water under different land-use types is different. From agricultural streams (Table 1), Gibe stream has the highest $\mathrm{NH}_{4}-\mathrm{N}$ concentration when compared with Merewa and Gulufa streams. Upstream of Gibe site (G1 and G2), there is intensive cultivation of crops and there is fertilizer use that can be moved to streams in line with report of other authors (Ranalli and Macady 2010; Mouri and Oki 2011).

In contrast, mean SRP concentration was greater in urban streams followed by agricultural streams, while in forest stream lowest concentration was absorbed. According to Zhou et al. 2016; Iseyemi et al. 2018; Jones et al. 2001; and Ding et al. 2016, these is the indicator of land-use effect on water quality.

DO saturation was high in forest stream sites than agricultural streams and urban streams. DO concentration was highest in forest stream sites when compared with agricultural streams that range from $6.57 \mathrm{mg} / \mathrm{l}$ to $5.53 \mathrm{mg} / \mathrm{l}$. In line with other authors like Ding et al. 2016 and Bernot et al. 2010, this is due to riparian land cover change. Thus, forest streams have high dissolved oxygen and lower water temperature because of riparian vegetation cover. For urban streams, DO ranges from $7.11 \mathrm{mg} / \mathrm{l}$ to $0.73 \mathrm{mg} / \mathrm{l}$ higher in Kito stream, medium in Kochi stream and lower in Awetu streams. It shows decrement downstream in all sites of the land uses. As reported by Bernot et al. 2010, dissolved oxygen is different from land use to forested streams and from upstream to downstream responding to organic pollution and water temperature.

Measures of pollution indicators, $\mathrm{COD}$ and $\mathrm{BOD}_{5}$, were greater at urban stream than forest and agricultural streams. Correspondingly, the value of COD in agricultural stream was greater than forest stream (Tables 1, 2 and 3). Among agricultural streams, Gulufa stream sites have the highest value of COD when compared with Merewa stream and Kochi stream has the highest value (nearly same to Gulufa stream). $\mathrm{BOD}_{5}$ was higher in all urban streams and lower in forest and agricultural streams. Other authors such as Mouri and Oki 2011, and Ding et al. 2016 have reported that wastes discharged from households, hotels and institutions are the main causes of organic waste leading to COD and BOD loads. In line with Chang 2008 and Ranalli and Macady 2010, our result reveals the more severely impaired urban and agricultural streams and then the more organic loads.

Electrical conductivity and turbidity were higher in urban and agricultural streams than forest stream sites as it was reported by Yu et al. 2016; Turner and Rabalias 2003; Ding et al. 2016. Water temperature varies among all sites of land uses, and the highest value was observed in agricultural stream and urban, while reference stream was similar to agricultural streams in line with Bu et al. 2014; Zhou et al. 2016; Likens and Bormann 1974; Bohlke and Denver 1995; and
Mulholland 1992. The analysis of one-way ANOVA showed that all of the parameters were significantly different among all sites with different land-use types $(P<0.05)$. However, water temperature did not differ statistically among sites (one-way ANOVA: $F=0.987, P=0.494$ ).

NMDS ordination analysis discriminated the studied streams into three groups (Fig. 2). All sites of agricultural and forest streams were similar, while sites of urban streams were categorized into two groups: A2, A3 and $\mathrm{KO} 1, \mathrm{KO} 2$, KO3. Physicochemical parameters such as $\mathrm{BOD}_{5}$, SRP, current and turbidity were directly correlated with A2 and $\mathrm{A} 3$, while ambient temperature, ammonium, COD, EC and discharge were with $\mathrm{KO} 1, \mathrm{KO} 2$ and $\mathrm{KO} 3$. As reported by Chang 2008; Bernot et al. 2010; Bohlke and Denver 1995; and Mulholland 1992, this shows that physicochemical parameters such as DO, nitrate, water temperature and depth and wet width were discriminating variation among agricultural streams from urban sites.

The cluster analysis was performed by using major physicochemical parameters, which shaped three main clusters (Fig. 3). Clusters clearly discriminated water quality among the dominant land-use types running along the study catchment. The forest stream and agricultural streams, namely Merewa, Gibe and Gulufa, were clustered together. The second cluster comprises only urban streams (Kito and Kochi), whereas the third cluster separately contains Awetu which is a heavily impaired urban stream as compared to reference sites. It was reported by Roy 2018 that agricultural and urban streams have similar physicochemical parameters. But here agricultural streams resemble more forested streams (reference site) than urban streams, indicating that urbanization

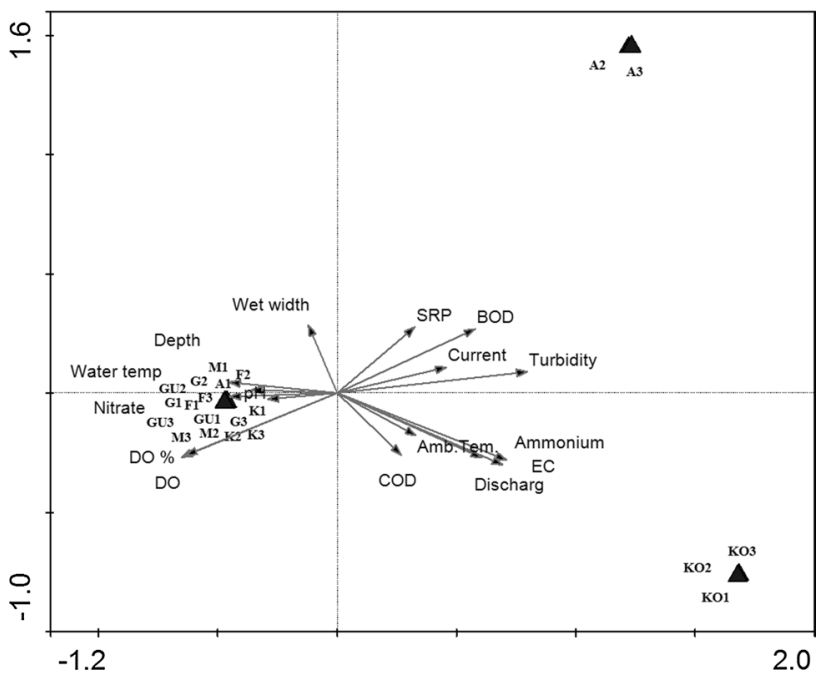

Fig. 2 Nonmetric Multidimensional Scaling (NMDS) analysis of physicochemical parameters of water across all stream sites of agricultural, forest and urban catchment area of southwest, Ethiopia. Stress value $=0.004$ 


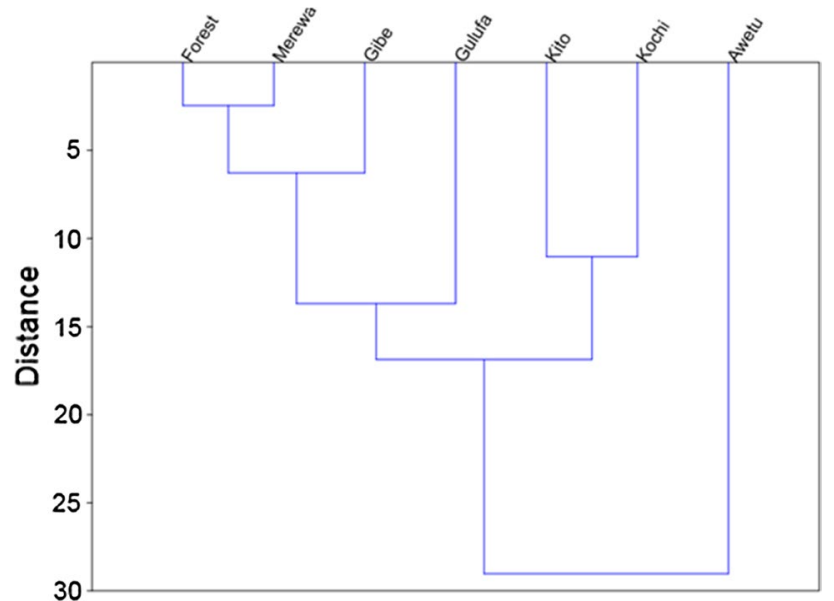

Fig. 3 Cluster analyses of streams from all types of land use

severely impaired water quality than agriculture. Therefore, cluster analyses have definitely illustrated the difference in study streams in physicochemical water quality due to landuse types.

\section{Conclusion}

The physicochemical water quality of study streams decreased from forest to agricultural and urban streams, respectively. The highest concentration of $\mathrm{NO}_{3}-\mathrm{N}$ was measured in heavily polluted agricultural stream sites (Gulufa stream site). In contrast to agricultural stream sites, concentration of $\mathrm{NO}_{3}-\mathrm{N}$ for urban stream is greater for slightly affected sites (Kito), while heavily polluted sites (Awetu) have moderate concentration. $\mathrm{NO}_{3}-\mathrm{N}$ concentration has no significant change from upstream to downstream of forest and agricultural streams, but for urban steams it has shown increment from upstream to downstream. Greater mean $\mathrm{NH}_{4}-\mathrm{N}$ was measured at agricultural and urban stream than forest streams. Concentration of SRP is greater for urban stream sites followed by agricultural streams; conversely, dissolved oxygen is higher for forest followed by agricultural streams. The higher measurement for COD and $\mathrm{BOD}_{5}$ was recorded at urban sites, while the least was recorded for forest stream. NMDS has discriminated the sites into three groups of land-use types. The performed cluster analyses also categorized streams into three main groups based on physicochemical water quality. Then, we conclude that water quality of urban stream is highly impaired than agriculture streams, whereas forested streams have improved water quality. Based on our result, we recommend that inappropriate disposal of wastes in urban area and intensive agricultural activities need to be monitored by concerned body, since they are degrading water quality of freshwater resources.
Stream restoration projects, reforestation and conservation of riparian vegetations should be encouraged in the study area for sustainable management of freshwater resources.

Acknowledgements The authors acknowledge Jimma University for financial and material support. Also we want to acknowledge laboratory technicians of Environmental Health Science.

Funding The author(s) received no specific funding for this work.

\section{Compliance with ethical standards}

Conflict of interest The authors declare that they have no conflict of interest.

Open Access This article is licensed under a Creative Commons Attribution 4.0 International License, which permits use, sharing, adaptation, distribution and reproduction in any medium or format, as long as you give appropriate credit to the original author(s) and the source, provide a link to the Creative Commons licence, and indicate if changes were made. The images or other third party material in this article are included in the article's Creative Commons licence, unless indicated otherwise in a credit line to the material. If material is not included in the article's Creative Commons licence and your intended use is not permitted by statutory regulation or exceeds the permitted use, you will need to obtain permission directly from the copyright holder. To view a copy of this licence, visit http://creativecommons.org/licenses/by/4.0/.

\section{References}

American Public Health Association (APHA) (1996) Standard methods for examination of water and Wastewater. American Public Health Association, Washington

Arjen, Hoekstra (2010): The relation between international trade and freshwater scarcity, WTO Staff Working Paper, No. ERSD-2010 05, World Trade Organization (WTO), Geneva

Bernot MJ, Sobota DJ, Hall RO, Patrick J, Mulholland DWK, Webster JR, Jennifer LT, Linda R, Lee W et al (2010) Inter-regional comparison of land-use effects on stream metabolism. Freshw Biol :1874-1890. https://doi.org/10.1111/j.1365-2427.2010.02422

Bohlke JK, Denver JM (1995) Combined use of groundwater dating chemical, and isotopic analyses to resolve the history and fate of nitrate contamination in two agricultural watersheds, Atlantic Coastal Plain, Maryland. Water Resour Res. https://doi. org/10.1029/95WR01584

Bray JR, Curtis JT (1957) An ordination of the upland forest communities of Southern Wisconsin. Ecol Monogr. https://doi. org/10.2307/1942268

Bu H, Meng W, Zhang Y, Jun W (2014) Relationships between land use patterns and water quality in the Taizi River basin. China Ecolo Indicat 41(2014):187-197

Buda AR, DeWalle DR (2009) Dynamics of stream nitrate sources and flow pathways during stormflows on urban, forest and agricultural watersheds in central Pennsylvania. USA Hydrol Process 23:3292-3305. https://doi.org/10.1002/hyp.7423

Chang H (2008) Spatial analysis of water quality trends in the Han River basin. South Korea Water Res 42(2008):3285-3304

De Gerónimo E, Aparicio V, Bárbaro S, Portocarrero R, Jaime S, Costa J (2014) Presence of pesticides in surface water from four sub-basins in Argentina. Chemosphere. https://doi.org/10.1016/j. chemosphere.2014.01.039 
Ding J, Jiang Y, Liu Q, Hou Z, Liao J, Lan Fu, Peng Q (2016) Influences of the land use pattern on water quality in low-order streams of the Dongjiang River basin, China: a multi-scale analysis. Sci Total Environ 551-552:205-216

Ebenstein A (2012) The consequences of industrialization: evidence from water pollution and digestive cancers in china. Rev Econ Stat 94(1):186-201

Gardner O, Engelman R (1997) Sustaining water easing scarcity: a second update.

Likens GE, Bormann FH (1974) Linkages between terrestrial and aquatic ecosystems. Bioscience 24(8):447-456. https://doi. org/10.2307/1296852

Hall R, Leavitt R (1999) Effects of agriculture, urbanization, and climate on water quality in the northern Great Plains. Limnol Oceanogr 44(3, part 2):739-756

Iseyemi O, Farris L, Moore T, Locke M, Choi S (2018) Phosphorus dynamics in agricultural drainage ditches: an influence of landscape properties. Soil Water Conserv Soc 73:558-566

Jones B, Neale A, Nash M, Remortel R, Wickham J, Riitters K, O’Neill R (2001) Predicting nutrient and sediment loadings to streams from landscape metrics: a multiple watershed study from the United States Mid-Atlantic Region. Landscape Ecol 16(4):301-312

Kail J, Arle J, Jähnig S (2012) Limiting factors and thresholds for macroinvertebrate assemblages in European rivers: Empirical evidence from three datasets on water quality, catchment urbanization, and river restoration. Ecol Ind 18(2012):63-72

Lenat DR (1984) Agriculture and stream water quality: a biological evaluation of erosion control practices. Environ Manage 8(4):333-344

Li S, Sheng G, Wenzhi L, Hongyin H (2008) Quanfa Zhang Water quality in relation to land use and land cover in the upper Han River Basin. China Catena 75(2008):216-222

Luo K, Hu X, He Q, Wu Z, Cheng H, Hu Z (2017) Mazumder A (2017) Impacts of rapid urbanization on the water quality and macroinvertebrate communities of streams: a case study in Liangjiang New Area. China Sci Total Environ. https://doi.org/10.1016/j.scito tenv.2017.10.068

McGrane S (2016) Impacts of urbanization on hydrological and water quality dynamics, and urban water management: a review. Hydrol Sci J 61(13):2295-2311. https://doi.org/10.1080/02626 667.2015.1128084

Mekonen S, Argaw R, Simanesew A, Houbraken M, Senaeve D, Ambelu A (2016) Pesticide residues in drinking water and associated risk to consumers in Ethiopia. Chemosphere 162:252-260. https://doi.org/10.1016/j.chemosphere.2016.07.096

Mereta ST, Boets P, Bayih AA, Malu A, Ephrem Z, Sisay A, Endale H, Yitbarek M, Jemal A, De Meester L, Goethals PLM (2012) Analysis of environmental factors determining the abundance and diversity of macroinvertebrate taxa in natural wetlands of Southwest Ethiopia. Ecol Inf 7:52-61

Mouri G, Oki T (2011) Spatial and temporal variation in nutrient parameters in stream water in a rural-urban catchment Effects of land cover and human impact Shikoku, Japan. J Environ Manag. https://doi.org/10.1016/j.jenvman.2011.03.005

Mulholland PJ (1992) Regulation of nutrient concentrations in a temperate forest stream: roles of upland, riparian, and instream processes. Am Soc Limnol Oceanogr. https://doi.org/10.4319/ lo.1992.37.7.1512
Pires N, Muniz D, Kisaka T, Simplicio N, Bortoluzzi L, Lima J (2015) Filho E (2015) Impacts of the urbanization process on water quality of Brazilian Savanna Rivers: the Case of Preto River in Formosa, Goiás State, Brazil. Int J Environ Res Public Health 12(9):10671-10686. https://doi.org/10.3390/ijerph120910671

Ranalli AJ, Macalady DL (2010) The importance of the riparian zone and in-stream processes in nitrate attenuation in undisturbed and agricultural watersheds-A review of the scientific literature. J Hydrol 389(2010):406-415. https://doi.org/10.1016/j.jhydr ol.2010.05.045

Ren W, Zhong Y, Meligrana J, Anderson B, Watt E, Chen J, Leung H (2003) Urbanization, land use, and water quality in Shanghai 1947-1996. Environ Int 29(2003):649-659

Ridoutt B, Pfister S (2010) A revised approach to water foot printing to make transparent the impacts of consumption and production on global freshwater scarcity. Global Environ Change 20(1):113-120

Rock MT (1998) Freshwater use, freshwater scarcity and socioeconomic development. J Environ Develop 7(3):278-301

Roy K, Karim R, Akter F, Islam S, Ahmed K, Rahman M, Datta D (2018) Khan S (2018) Hydrochemistry, water quality and land use signatures in an ephemeral tidal river: implications in water management in the southwestern coastal region of Bangladesh. Appl Water Sci 8:78. https://doi.org/10.1007/s13201-018-0706-x

Temesgen E, Seyoum L (2018) Spatial and seasonal variation in physicochemical parameters and heavy metals in Awash River. Ethiopia Appl Water Sci 8:177. https://doi.org/10.1007/s1320 1-018-0803-x

Teng Y, Yang J, Zuo R, Wang J (2011) Impact of urbanization and industrialization upon surface water quality: a pilot study of Panzhihua mining town. J Earth Sci 22(5):658

Turner RE, Rabalai N (2003) Linking landscape and water quality in the mississippi river basin for 200 Years. Bioscience 53(6):563-572

Wallace JB, Eggert SL, Meyer JL, Webster JR (1997) Multiple trophic levels of a forest stream linked to terrestrial litter Inputs. Science 277(5322):102-104. https://doi.org/10.1126/scien ce. 277.5322 .102

Waziri M, Ogugbuaja O (2010) Interrelationships between physicochemical water pollution indicators: a case study of River YobeNigeria. Am J Sci Ind Res 1:76-80

Wondim Y, Mosa H, Alehegn M (2016) Physico-chemical water quality assessment of Gilgel Abay River in the Lake Tana Basin. Ethiopia Civil Environ Res 8(4):2016

Yogendra K, Puttaiah T (2008) Determination of Water Quality Index and Suitability of an Urban Water body in Shimoga Town, Karnataka. In: The 12th World Lake Conference, pp 342-346

Yu S, Xu Z, Wu W, Zuo D (2016) Effect of land use types on stream water quality under seasonal variation and topographic characteristics in the Wei River basin, China. Ecol Indicat 60:202-212

Zhou P, Huang J, Pontius Jr RG, Hong H (2016) New insight into the correlations between land use and water quality in a coastal watershed of China: does point source pollution weaken it? Sci Total Environ 543:591-600

Publisher's note Springer Nature remains neutral with regard to jurisdictional claims in published maps and institutional affiliations. 